\title{
Aluminium Toxicity Targets in Plants
}

\author{
Sónia Silva \\ CESAM and Department of Biology, University of Aveiro, 3810-193 Aveiro, Portugal \\ Correspondence should be addressed to Sónia Silva, soniasilva@ua.pt \\ Received 30 November 2011; Accepted 21 May 2012 \\ Academic Editor: Helena Oliveira \\ Copyright (C) 2012 Sónia Silva. This is an open access article distributed under the Creative Commons Attribution License, which \\ permits unrestricted use, distribution, and reproduction in any medium, provided the original work is properly cited. \\ Aluminium (Al) is the third most abundant metallic element in soil but becomes available to plants only when the soil $\mathrm{pH}$ \\ drops below 5.5. At those conditions, plants present several signals of Al toxicity. As reported by literature, major consequences \\ of $\mathrm{Al}$ exposure are the decrease of plant production and the inhibition of root growth. The root growth inhibition may be \\ directly/indirectly responsible for the loss of plant production. In this paper the most remarkable symptoms of Al toxicity in plants \\ and the latest findings in this area are addressed. Root growth inhibition, ROS production, alterations on root cell wall and plasma \\ membrane, nutrient unbalances, callose accumulation, and disturbance of cytoplasmic $\mathrm{Ca}^{2+}$ homeostasis, among other signals of \\ $\mathrm{Al}$ toxicity are discussed, and, when possible, the behavior of Al-tolerant versus Al-sensitive genotypes under $\mathrm{Al}$ is compared.
}

\section{Introduction}

Aluminium (Al) ranks third in abundance among the Earth's crust elements, after oxygen and silicon, and is the most abundant metallic element. A large amount of $\mathrm{Al}$ is incorporated into aluminosilicate soil minerals, and very small quantities appear in the soluble form, capable of influencing biological systems [1].

Al bioavailability, and in consequence, toxicity, is mainly restricted to acid environments. Acid soils (with a $\mathrm{pH}$ of 5.5 or lower) are among the most important limitations to agricultural production. The production of staple food crops, in particular grain crops, is negatively influenced by acid soils [2]. Some agricultural practices, as removal of products from the farm, leaching of nitrogen below the plant root zone, inappropriate use of nitrogenous fertilizers, and build-up in organic matter, are causing further acidification of agricultural soils.

When $\mathrm{pH}$ drops below 5.5, aluminosilicate clays and aluminium hydroxide minerals begin to dissolve, releasing aluminium-hydroxy cations and $\mathrm{Al}(\mathrm{H} 2 \mathrm{O})_{6}{ }^{3+}\left(\mathrm{Al}^{3+}\right)$, that then exchange with other cations. On that conditions, $\mathrm{Al}^{3+}$ also forms the mononuclear species $\mathrm{AlOH}^{2+}, \mathrm{Al}(\mathrm{OH})_{2}{ }^{+}$, $\mathrm{Al}(\mathrm{OH})_{3}$, and $\mathrm{Al}(\mathrm{OH})_{4}$ [3]. The mononuclear $\mathrm{Al}^{3+}$ species and $\mathrm{Al}_{13}$ are considered as the most toxic forms $[4,5]$.
Although some crops (e.g., pineapple, tea) are considered tolerant to high levels of exchangeable $\mathrm{Al}$, for most crops it is a serious constraint. Species and genotypes within species greatly differ in their tolerance to Al. For most crops, fertilization and attempts of soil correction (e.g., liming) may not be enough per se to reduce Al toxicity (e.g., as the soil reaction remains strongly acid), and in most target countries these strategies may also be jeopardized by economical constrains [6]. Therefore, it is imperative to fully understand the mechanisms that are used by the Al-tolerant species to cope Al toxicity, as well which genotypes, within the most resistant/tolerant cereal species, are more suitable to grow in acidic soils in order to increase world cereal production. Furthermore, the development of new cultivars (or the reinvestment in ancient genotypes from $\mathrm{Al}$ rich regions) with increased Al-tolerance is fundamental and economic solution to increase world food production.

\section{Aluminium Toxicity}

2.1. Root Growth. A major consequence of $\mathrm{Al}$ toxicity is the inhibition of root growth, and this outcome has been reported during the last century (e.g., [7]) for innumerous species [8-15]. Consequently, root growth inhibition has been widely used to assess Al toxicity. 
Root growth is the combination of cell division and elongation. Only during the last decade, researchers started to look at the cell cycle (de)regulation induced by $\mathrm{Al}$, with some works focusing unbalances on mitosis phase and very few on other interphase phases (e.g., [15]). Decrease of mitotic activity was reported as a consequence of $\mathrm{Al}$ exposure in root tips of several species as wheat $[16,17]$, maize $[18,19]$, barley [20], and bean. [19]. Some authors defended that inhibition of cell elongation was the primary mechanism leading to root growth inhibition $[21,22]$. The reason for that is that root growth inhibition could occur within a short time period-30 min in Al-sensitive maize [23]—and that cell division is a slow process (cell cycle takes usually several hours to be completed). However, Doncheva et al. [18] reported inhibition of cell division (decrease of S-phase cells) in the proximal meristem after $5 \mathrm{~min} \mathrm{Al}$ exposure and inhibition of root cell division in the apical meristem within 10 or 30 minutes. Furthermore, $\mathrm{Al}$ can accumulate in the nuclei of cells in the meristematic region of the root tip within 30 minutes [15]. Therefore, whereas inhibition of cell elongation or cell division is the primary mechanism leading to root growth inhibition is still unclear. More recently, Yi et al. [24] reported that $\mathrm{Al}$ exposure led to abnormal progress through mitosis and induced micronuclei formation in Vicia faba roots, which is in agreement with Al-induced chromosome aberrations found in wheat roots [25] and Alinduced chromosome stickiness and breaks in Oryza sativa [26]. From the literature review, it is evident that $\mathrm{Al}$ leads to cell cycle unbalances, but many questions still remain to clarify. For example it still remains unclear how and where $\mathrm{Al}$ exerts its influence throughout the cell cycle, if these changes are species and region dependent (most studies are performed in root apices), how the putative changes are exerted through time, and/or if they may be reversible after Al removal.

The root growth inhibition and increase in root diameter observed in roots exposed to $\mathrm{Al}$ [27] suggested that plant cytoskeleton could be a cellular target of Al phytotoxicity [28]. Blancaflor et al. [28] and Horst et al. [29] studied Alinduced effects on microtubules and actin microfilaments and showed that microtubules and microfilaments are altered, in their stability, organization, and polymerization, when exposed to Al. Also, in Triticum turgidum Al treatment led to disorganization of actin filaments and formation of actin deposits [30]. Zhang et al. [31] showed that $\mathrm{Al}$ inhibited actin and profilin genes. Profilin, as an actin-binding protein, provides cells with the ability to remodel the cytoskeleton [32]. In Arabidopsis thaliana a decrease in profilin expression resulted in an elongation defect [33]. Furthermore, Sivaguru et al. [34] and Čiamporová [21] showed that organization of cytoskeleton is most sensitive in the distal transition zone of the root apex, providing evidence that this zone represents a potential target with respect to $\mathrm{Al}$ toxicity.

The most sensitive root zone to $\mathrm{Al}$ toxicity is under great attention. Earlier, it was hypothesized that root cap played a major role in the mechanism of $\mathrm{Al}$ toxicity/protection [35]. However, Ryan et al. [9] demonstrated that the removal of the root cap had no effect on the Al-induced inhibition of root growth in maize. Furthermore, the same authors also suggested that the meristem is the primary site of $\mathrm{Al}$ toxicity. Later, Sivaguru and Horst [36], applying $\mathrm{Al}$ to $1 \mathrm{~mm}$ root segments, reported that $\mathrm{Al}$ accumulation in the distal transition zone (DTZ: $1-2 \mathrm{~mm}$ ) led to a rapid inhibition of the root elongation and suggested that this root zone is the primary target of $\mathrm{Al}$ in an $\mathrm{Al}$-sensitive maize cultivar.

2.2. Oxidative Stress. Al-induced oxidative stress and changes in cell wall properties have been suggested as the two major factors leading to $\mathrm{Al}$ toxicity $[22,37]$. Oxidative stress occurs when any condition disrupts the cellular redox homeostasis. The reactive oxygen species (ROS) have the capacity to oxidize cellular components such as lipids, proteins, enzymes, and nucleic acids, leading to cell death. Metals are known to act as catalysts in ROS production and to induce oxidative damage in plants. $\mathrm{Al}$ itself is not a transition metal and cannot catalyze redox reactions; however, $\mathrm{Al}$ exposure leads to oxidative stress [37-43]. Because aluminium ions form electrostatic bonds preferentially with oxygen donor ligands (e.g., carboxylate or phosphate groups), cell wall pectin and the outer surface of the plasma membrane seem to be major targets of aluminium [37]. Al binding to biomembranes leads to rigidification [44], which seems to facilitate the radical chain reactions by iron $(\mathrm{Fe})$ ions and enhance the peroxidation of lipids [38].

$\mathrm{Al}$ induction lipid peroxidation has been reported for some species, including barley [45], sorghum [46], triticale [42], rice [40], greengram [47], and wheat [48]. Yamamoto et al. [37] found that, for Pisum sativum seedlings treated with $\mathrm{Al}$ in a simple $\mathrm{Ca}$ solution, $\mathrm{Al}$ accumulation, lipid peroxidation, and callose production had a similar distribution on the root apex surface and were accompanied by root growth inhibition. However, the loss of membrane integrity was only detected at the periphery of the cracks on the surface of the root apex. Furthermore, Yamamoto et al. [38] concluded that the $\mathrm{Al}$ enhancement of lipid peroxidation is an early symptom of $\mathrm{Al}$ accumulation and appears to cause partly callose production, but not root growth inhibition. Later, however, in maize, $\mathrm{Al}$ treatment did not induce lipid peroxidation, indicating that lipids are not the primary cellular target of oxidative stress in maize [39]. So, it seems that cellular target of oxidative stress depends on plant species.

Plant cells are equipped with a defensive system composed by enzymatic antioxidants such as catalase (CAT), ascorbate peroxidase (APX), guaiacol peroxidase (GPOX), superoxide dismutase (SOD), monodehydroascorbate reductase (MDHAR), dehydroascorbate reductase (DHAR), glutathione-S-transferase (GST), and gluthatione reductase (GR) and nonenzymatic antioxidants such as ascorbate (AsA), glutathione (GSH), $\alpha$-tocopherol, and carotenoids that help to detoxify the ROS. Some works reported ROS production and alterations in the antioxidant system as a consequence of $\mathrm{Al}$ exposure. In pea seedlings, ROS production is detected in root apex after two hours of $\mathrm{Al}$ exposure and increased with time exposure [38]. In maize roots, $\mathrm{Al}$ treatment also led to increase in ROS production rate in all epidermal cells, only within $10 \mathrm{~min}$ of $\mathrm{Al}$ exposure and continued to increase during $\mathrm{Al}$ exposure [41]. APX and 
SOD activity increased in roots of both Al-resistant and Alsensitive triticale cultivars (with higher magnitude in the sensitive one), but changes were detected first in the sensitive cultivar (6h) and then in the resistant (12 h) [42]. Boscolo et al. [39] reported for maize root tips an increase of SOD and APX activities. Furthermore, these authors found that SOD and APX activity is inversely proportional to root growth rate and, therefore, suggested that the increase of $\mathrm{O}_{2}{ }^{-}$and $\mathrm{H}_{2} \mathrm{O}_{2}$ production is related to $\mathrm{Al}$ toxicity. An increase in SOD, APX, and GR activities was reported for greengram seedlings, whereas a decrease in CAT activity and glutathione and ascorbate contents was also found at higher $\mathrm{Al}$ concentrations [47]. These authors justified the decrease in CAT activity due to the fact that this enzyme is photosensitive and, therefore, needs constant synthesis and suggested that glutathione and ascorbate may be able to detoxify the ROS directly [47]. Devi et al. [49] found an increase in manganese superoxide dismutase (MnSOD) activity in both sensitive and tolerant cell lines of tobacco and in AsA and GSH contents, mostly in the tolerant line. These data indicated that AsA and GSH seem to be in part responsible for the tolerance mechanisms of the tolerant line to Al. Activities of SOD, CAT, and APX also increased in roots of plants and in cultured tea cells exposed to $\mathrm{Al}$ [50]. owever, However, plants of this species provide a complex scenario compared with other models, as aluminium may show a stimulatory effect on plant growth. That increase seemed to result in increased membrane integrity, since lipid peroxidation reduced with $\mathrm{Al}$ exposure [50].

These findings reporting increase of antioxidants (enzymatic and nonenzymatic) are accompanied with others that prove gene regulation associated with oxidative stress. For example, Ezaki et al. [51] expressed nine genes derived from Arabidopsis, tobacco, wheat, and yeast in Arabidopsis ecotype Landsberg. An Arabidopsis blue-copper-binding protein gene $(A t B C B)$, a tobacco glutathione-S-transferase gene (parB), a tobacco peroxidase gene (NtPox), and a tobacco GDP-dissociation inhibitor gene (NtGDI1) conferred a degree of resistance to Al: significative differences in relative root growth and decrease in $\mathrm{Al}$ content and oxidative damages. They also showed that overexpression of three $\mathrm{Al}$-induced genes in plants conferred oxidative stress resistance. Furthermore, overexpression of the parB gene simultaneously conferred resistance to both $\mathrm{Al}$ and oxidative stresses. Therefore, Ezaki and coworkers concluded that some of the genes induced during $\mathrm{Al}$ exposure and oxidative stresses play protective roles against both stresses. Cançado et al. [52] identified a maize $\mathrm{Al}$-inducible cDNA encoding a glutathione-Stransferase (GST). Expression of that gene (GST27.2) was upregulated in response to various $\mathrm{Al}$ concentrations in both Al-tolerant and Al-sensitive maize lines. Recently, using Alsensitive Medicago truncatula cultivar Jemalong genotype A17, 324 genes were upregulated and 267 genes were downregulated after $\mathrm{Al}$ exposure [53]. Upregulated genes were enriched in transcripts involved in cell-wall modification and abiotic and biotic stress responses, while downregulated genes were enriched in transcripts involved in primary metabolism, secondary metabolism, protein synthesis and processing, and the cell cycle. Known markers of Al-induced gene expression including genes associated with oxidative stress and cell wall stiffening were differentially regulated in that study [53]. For maize plants, $\mathrm{Al}$ exposure led to alteration in gene expression, mostly in the $\mathrm{Al}$-sensitive genotype. Although Al-sensitive genotype showed changes in the expression of more genes, several Al-regulated genes exhibited higher expression in the tolerant genotype [54]. So, it is clear that expression of some genes confers $\mathrm{Al}$ resistance and contributes to reduce oxidative stress.

2.3. Cell Wall, Plasma Membrane, and Nutrient Unbalances. $\mathrm{Al}$ accumulation is primarily and predominantly in the root apoplast (30-90\% of the total absorbed Al) (e.g., $[42,55])$ of peripheral cells and is only very slowly translocated to more central tissues $[19,56,57]$. The primary binding of $\mathrm{Al}^{3+}$ in the apoplast is probably the pectin matrix, with its negatively charged carboxylic groups $[57,58]$.

Several works reported increases of pectin levels in Alsensitive genotypes [29, 43, 57-60], and some also detected increase in $\mathrm{Al}$ contents in the same sensitive genotypes [29, $57,60]$. These findings indicated that pectin plays a major role in the binding of $\mathrm{Al}$ and suggested that some of the additional $\mathrm{Al}$ accumulation in sensitive genotypes bound in the newly formed cell wall pectin $[43,57,58]$. Binding of $\mathrm{Al}$ to the pectin matrix and other cell wall constituents could alter cell wall characteristics and functions such as extensibility [61], porosity, and enzyme activities thus leading to inhibition of root growth [57]. Another mechanism for Al toxicity targeted to the apoplast invokes a rapid and irreversible displacement of $\mathrm{Ca}^{2+}$ from cell wall components by $\mathrm{Al}$ ions [22, 61]. Accumulation of $\mathrm{Al}$ occurs predominantly in the root apoplast. Nevertheless, $\mathrm{Al}$ accumulates also in the symplast and with a fast rate [19]. Recently, Xia et al. [62] reported a transporter, Nrat1 (Nramp aluminium transporter 1), specific for $\mathrm{Al}^{3+}$ localized at the plasma membrane of all rice root tips cells, except epidermal cells. Those authors referred that the elimination of the Nrat1 enhanced $\mathrm{Al}$ sensitivity, decreased $\mathrm{Al}$ uptake, increased $\mathrm{Al}$ binding to cell wall and concluded that this transporter is required for prior step of final $\mathrm{Al}$ detoxification through sequestration of $\mathrm{Al}$ into vacuoles. Furthermore, given its physicochemical properties, $\mathrm{Al}$ can interact strongly with the negatively charged plasma membrane. For instance, Al can displace other cations (e.g., $\mathrm{Ca}^{2+}$ ) that may form bridges between the phospholipid head groups of the membrane bilayer [63]. Furthermore, $\mathrm{Al}$ interaction with plasma membrane could lead to depolarization of the transmembranar potential (e.g., [64]) and/or reduction of $\mathrm{H}^{+}$-ATPase (e.g., [65]) which, in turn, can alter the activities of ions near the plasma membrane surface and impede the formation and maintenance of the transmembrane $\mathrm{H}^{+}$gradient [2] . Moreover, $\mathrm{Al}$ changes in plasma membrane can modify the uptake of several cations (e.g., $\mathrm{Ca}^{2+}, \mathrm{Mg}^{2+}, \mathrm{K}^{+}, \mathrm{NH}_{4}{ }^{+}$) $[8,66-$ $68]$. These changes are related to direct $\mathrm{Al}^{3+}$ interactions with plasma membrane ion channels [69] and changes in membrane potential.

Nutritional unbalances induced by $\mathrm{Al}$ exposure were reported for several plant species. Eleven families of pteridophytes presented different nutritional unbalances (mostly 
in $\mathrm{Ca}, \mathrm{Mg}, \mathrm{P}, \mathrm{K}$ ) depending on $\mathrm{Al}$ accumulation [70], and in maize, $\mathrm{Al}$ had negative effects on the uptake of macroand micronutrients, with $\mathrm{Ca}$ and $\mathrm{Mg}$ being the macroand $\mathrm{Mn}$ and $\mathrm{Zn}$ the micronutrients more affected [68]. Also, the maize Al-tolerant genotypes accumulated higher concentration of $\mathrm{Ca}, \mathrm{Mg}$ [68], and $\mathrm{K}$ [71] than the sensitive genotypes. In wheat, both sensitive and tolerant genotypes presented a decrease in $\mathrm{K}$ and $\mathrm{Mg}$ contents in roots, whereas $\mathrm{Ca}, \mathrm{Al}, \mathrm{Si}$ contents increased [72]. However, the sensitive wheat genotype showed more nutritional unbalances and $\mathrm{Al}$ accumulation than the tolerant one in both roots and shoots [72]. Al exposure led to an increase of $\mathrm{Ca}$ accumulation in rye-sensitive genotype, contrarily to the tolerant rye genotype [73]. However, other studies reported different results in Al-induced nutritional imbalances in maize: Lidon et al. [74] referred that all elements in roots, except $\mathrm{K}, \mathrm{Mn}$, and $\mathrm{Zn}$, increased in Al-treated roots and that in shoots $\mathrm{Ca}$ and $\mathrm{Mg}$ had little variation. Reference [67] reported that only the specific absorption rate of $\mathrm{B}$ was correlated to the $\mathrm{Al}$ induced root growth inhibition. Al exposure led to decrease in $\mathrm{K}, \mathrm{Mg}, \mathrm{Ca}$, and $\mathrm{P}$ contents and uptake in rice plants, and, as observed in maize, the tolerant cultivar presented less negative effects in nutrient content than the sensitive one [75]. In tomato cultivars, $\mathrm{Al}$ exposure decreased the content of $\mathrm{Ca}, \mathrm{K}, \mathrm{Mg}, \mathrm{Mn}, \mathrm{Fe}$, and $\mathrm{Zn}$ in roots, stems, and leaves [76]. Zobel et al. [27] related changes in fine root diameter with changes in concentration of some nutrients, as N, P, and Al. It seems that the differential tolerance to $\mathrm{Al}$ may be due to their differences in uptake, ability to keep adequate concentrations and to use the nutrients efficiently. Differences in nutrient uptake, accumulation, and translocation are evident between plant species and within each species. Furthermore, since each author utilized different Al concentrations, diverse nutritive solutions and time exposures, it is difficult to make a general and accurate model of Al-induced nutritional unbalances.

2.4. Cytoplasmic $\mathrm{Ca}^{2+}$. Disturbance of cytoplasmic $\mathrm{Ca}^{2+}$ homeostasis is believed to be the primary target of Al toxicity [77] and may be involved in the inhibition of the cell division or root elongation by causing potential disruptions of $\mathrm{Ca}^{2+}$ dependent biochemical and physiological processes $[34,77$, 78].

In wheat root apices, [44] found that $\mathrm{Al}$ inhibits $\mathrm{Ca}^{2+}$ dependent phospholipase $\mathrm{C}$, which acts on the lipid substrate phosphatidylinositol-4,5-biphosphate. The authors hypothesized that phosphoinositide signaling pathway might be the initial target of Al. In accordance, Zhang et al. [31] found Al-induced inhibition of genes related to phosphoinositide signaling pathway and hypothesized that the gene inhibition could result in disruption of this pathway. Also, it was reported that components of the actin-based cytoskeleton interact directly with phospholipase C in oat [79].

Most works reported an increase in cytoplasmic $\mathrm{Ca}^{2+}$ when plants were exposed to $\mathrm{Al}[13,80,81]$. However, Jones et al. [82] reported a decrease in cytoplasmic $\mathrm{Ca}^{2+}$ in tobacco cell cultures in the presence of Al. Furthermore, Zhang and Rengel [80] reported an increase in cytoplasmic $\mathrm{Ca}^{2+}$ in two lines with different tolerance to $\mathrm{Al}$ and correlated it with the inhibition of root growth in both lines. Moreover, Ma et al. [13] correlated cytoplasmic $\mathrm{Ca}^{2+}$ to root growth response. Moreover, alteration in cytoplasmic $\mathrm{Ca}^{2+}$ homeostasis can occur within few minutes (20-30 minutes) in root hair tips of Arabidopsis thaliana [82].

It is certain that $\mathrm{Al}$ exposure influences cytoplasmic $\mathrm{Ca}^{2+}$ homeostasis, but it is still unclear if it is a primary cause of Alinduced inhibition of root growth or a secondary effect. The source of $\mathrm{Ca}^{2+}$ for the increase of cytosolic $\mathrm{Ca}^{2+}$ activity could be extracellular and/or intracellular but is still insufficiently documented, as well the effects on increased cytosolic $\mathrm{Ca}^{2+}$ (for review see [77]).

2.5. Callose. The induction of callose (1,3- $\beta$-D-glucan) formation in $\mathrm{Al}$-exposed roots has been reported in many plant species (e.g., [20, 41, 67, 83-86]). Al-induced callose formation in root tips is recognized as an excellent indicator of Al sensibility [81, 86-90], and some works negatively correlated root elongation with callose formation during Al exposure (e.g., $[86,91])$. Recently, it was reported that $\mathrm{Al}$ induced callose accumulation not only in the root meristematic regions but also in mature zones, in both wheat and rye genotypes $[72,73]$. In maize roots, Jones et al. [41] found a close spatial and temporal coordination between $\mathrm{Al}$ accumulation and callose production in roots. Also, in wheat, callose accumulation in root tissues was progressive with Al-exposure, and, contrarily to the tolerant genotype, the sensitive one presented callose deposition at inner cell layers [72, 73]. Still, Tahara et al. [86] reported that, in some Myrtaceae species, induction of callose formation was not accompanied by root growth inhibition and suggested that callose formation is a more sensitive indicator to $\mathrm{Al}$ than root elongation.

Since $\mathrm{Al}$ induces a transient rise of cytosolic $\mathrm{Ca}^{2+}$, an increase of callose accumulation under $\mathrm{Al}$ stress is not unexpected. Cytosolic $\mathrm{Ca}^{2+}$ is one of the prerequisites for the induction of callose synthesis, but not the only factor modulating increases in callose synthesis and deposition [81]. Callose formation, as response to $\mathrm{Al}$, is described in sensitive and, to a lesser extent, in tolerant roots [85, 87]. In a less extent, callose deposition has been considered as a mechanism to prevent $\mathrm{Al}$ from penetrating into the apoplast. Also, this accumulation is reported to inhibit the symplastic transport and cell communication by blocking plasmodesmata, avoiding Al-induced lesions in the symplast [92]. However, callose deposition in sensitive roots has also been shown to lead to uncontrolled rigidity of cell walls [41] leading ultimately to protoplast degradation.

2.6. Others. Al-induced effects/damages are first detected in the root system $[18,93]$. Changes in the root system may affect nutrient uptake, which can lead to nutritional deficiencies in shoots and leaves [94]. Except for Al-accumulator plants, $\mathrm{Al}$ accumulates more in roots than in leaves [95]. In some species, Al-induced alterations in leaves were considered indirect, since $\mathrm{Al}$ accumulation was not detected in leaves [94]. Nevertheless, alterations in leaves induced by $\mathrm{Al}$ exposure were reported for many species. Several works reported leaves biomass reduction [96], thickness [95], lipid 
peroxidation [97], nutritional imbalances [98], changes in the photosynthetic performance [99], and changes in chlorophyll contents [96, 97, 99, 100], among others. Reductions in carbon dioxide $\left(\mathrm{CO}_{2}\right)$ assimilation rate due to $\mathrm{Al}$ toxicity are reported for several species [94, 99-101], and some works indicated that $\mathrm{Al}$ exposure induced damage of the photosystem II $[97,102]$. Very few works focused on the consequence of $\mathrm{Al}$ treatment in the carbohydrate metabolism. The effects of $\mathrm{Al}$ exposure on Ribulose-1,5-bisphosphate carboxylase/oxygenase (RuBisCo) content and activity are still unclear, and the few reports available were performed in citrus $[99,100]$ and in wild rice [103].

\section{Conclusions}

Most studies on Al toxicity are performed with different media composition, Al concentration, and period of exposure. Also, there is a large variation between genotypes. This battery of nonharmonized experimental data needs caution during interpretation, mostly concerning generalizations of functional models. So, it would be important to uniform the experimental procedures in order to better comprehend the plant response to $\mathrm{Al}$ exposure and the mechanisms of $\mathrm{Al}$ tolerance.

\section{Acknowledgments}

FCT/MCT supported this work (POCI/AGR/58174/2004) and S. Silva was supported by (SFRH/BPD/74299/2010) grants.

\section{References}

[1] H. M. May and D. K. Nordstrom, "Assessing the solubilities and reactions kinetics of aluminuous mineral in soils," in Soil Acidity, B. Ulrich and M. E. Summer, Eds., pp. 125-148, Springer, Berlin, Germany, 1991.

[2] L. V. Kochian, M. A. Piñeros, and O. A. Hoekenga, "The physiology, genetics and molecular biology of plant aluminum resistance and toxicity," Plant and Soil, vol. 274, no. 1-2, pp. 175-195, 2005.

[3] S. K. Panda and H. Matsumoto, "Molecular physiology of aluminum toxicity and tolerance in plants," Botanical Review, vol. 73, no. 4, pp. 326-347, 2007.

[4] T. B. Kinraide, "Identity of the rhizotoxic aluminium species," Plant and Soil, vol. 134, no. 1, pp. 167-178, 1991.

[5] L. V. Kochian, "Cellular mechanisms of aluminum toxicity and resistance in plants," Annual Review of Plant Physiology and Plant Molecular Biology, vol. 46, pp. 237-260, 1995.

[6] B. Marschner, U. Henke, and G. Wessolek, "Effects of meliorative additives on the adsorption and binding forms of heavy-metals in contaminated topsoil from a former sewage farm," Zeitschrift fur Pflanzenernahrung und Bodenkunde, vol. 158, pp. 9-14, 1995.

[7] W. S. Eisenmenger, "Toxicity of aluminum on seedlings and action of certain ions in the elimination of the toxic effects," Plant Physiology, vol. 10, no. 1, pp. 1-25, 1935.

[8] F. Jan, "Aluminium effects on growth, nutrient net uptake and transport in 3 rice (Oryza sativa) cultivars with different sensitivity to aluminium," Physiologia Plantarum, vol. 83, no. 3, pp. 441-448, 1991.
[9] P. R. Ryan, J. M. Ditomaso, and L. V. Kochian, "Aluminium toxicity in roots: an investigation of spatial sensitivity and the role of the root cap," Journal of Experimental Botany, vol. 44, no. 2, pp. 437-446, 1993.

[10] Z. G. Shen, J. L. Wang, and H. Y. Guan, "Effect of aluminium and calcium on growth of wheat seedlings and germination of seeds," Journal of Plant Nutrition, vol. 16, no. 11, pp. 21352148, 1993

[11] S. A. Crawford and S. Wilkens, "Effect of aluminium on root elongation in two Australian perennial grasses," Australian Journal of Plant Physiology, vol. 25, no. 2, pp. 165-171, 1998.

[12] S. J. Ahn, M. Sivaguru, H. Osawa, G. C. Chung, and H. Matsumoto, "Aluminum inhibits the $\mathrm{H}^{+}$-ATpase activity by permanently altering the plasma membrane surface potentials in squash roots," Plant Physiology, vol. 126, no. 4, pp. 1381-1390, 2001.

[13] Q. Ma, Z. Rengel, and J. Kuo, "Aluminium toxicity in rye (Secale cereale): root growth and dynamics of cytoplasmic $\mathrm{Ca}^{2+}$ in intact root tips," Annals of Botany, vol. 89, no. 2, pp. 241-244, 2002.

[14] S. Kikui, T. Sasaki, M. Maekawa et al., "Physiological and genetic analyses of aluminium tolerance in rice, focusing on root growth during germination," Journal of Inorganic Biochemistry, vol. 99, no. 9, pp. 1837-1844, 2005.

[15] I. R. Silva, T. J. Smyth, D. F. Moxley, T. E. Carter, N. S. Allen, and T. W. Rufty, "Aluminum accumulation at nuclei of cells in the root tip. Fluorescence detection using lumogallion and confocal laser scanning microscopy," Plant Physiology, vol. 123, no. 2, pp. 543-552, 2000.

[16] G. Frantzios, B. Galatis, and P. Apostolakos, "Aluminium effects on microtubule organization in dividing root-tip cells of Triticum turgidum II. Cytokinetic cells," Journal of Plant Research, vol. 114, no. 1114, pp. 157-170, 2001.

[17] Y. Li, G. X. Yang, L. T. Luo et al., "Aluminium sensitivity and tolerance in model and elite wheat varieties," Cereal Research Communications, vol. 36, no. 2, pp. 257-267, 2008.

[18] S. Doncheva, M. Amenós, C. Poschenrieder, and J. Barceló, "Root cell patterning: a primary target for aluminium toxicity in maize," Journal of Experimental Botany, vol. 56, no. 414, pp. 1213-1220, 2005.

[19] S. Marienfeld, N. Schmohl, M. Klein, W. H. Schröder, A. J. Kuhn, and W. J. Horst, "Localisation of aluminium in root tips of Zea mays and Vicia faba," Journal of Plant Physiology, vol. 156, no. 5-6, pp. 666-671, 2000.

[20] S. Budikova and and K. Durcekova, "Aluminium accumulation in roots of Al-sensitive barley cultivar changes root cell structure and induces callose synthesis," Biologia, vol. 59, pp. 215-220, 2004.

[21] M. Čiamporová, "Morphological and structural responses of plant roots to aluminium at organ, tissue, and cellular levels," Biologia Plantarum, vol. 45, no. 2, pp. 161-171, 2002.

[22] S. J. Zheng and J. L. Yang, "Target sites of aluminum phytotoxicity," Biologia Plantarum, vol. 49, no. 3, pp. 321-331, 2005.

[23] M. Llugany, C. Poschenrieder, and J. Barcelo, "Monitoring of aluminium-induced inhibition of root elongation in four maize cultivars differing in tolerance to aluminium and proton toxicity," Physiologia Plantarum, vol. 93, no. 2, pp. 265-271, 1995.

[24] M. Yi, H. Yi, H. Li, and L. Wu, "Aluminum induces chromosome aberrations, micronuclei, and cell cycle dysfunction in root cells of Vicia faba," Environmental Toxicology, vol. 25, no. 2, pp. 124-129, 2010. 
[25] N. V. Bulanova, B. I. Synzynys, and G. V. Koz'min, "Aluminum induces chromosome aberrations in cells of wheat root meristem," Russian Journal of Genetics, vol. 37, no. 12, pp. 1455-1458, 2001.

[26] S. Mohanty, A. B. Das, P. Das, and P. Mohanty, "Effect of a low dose of aluminum on mitotic and meiotic activity, $4 \mathrm{C}$ DNA content, and pollen sterility in rice, Oryza sativa L. cv. Lalat," Ecotoxicology and Environmental Safety, vol. 59, no. 1, pp. 70-75, 2004.

[27] R. W. Zobel, T. B. Kinraide, and V. C. Baligar, "Fine root diameters can change in response to changes in nutrient concentrations," Plant and Soil, vol. 297, no. 1-2, pp. 243-254, 2007.

[28] E. B. Blancaflor, D. L. Jones, and S. Gilroy, "Alterations in the cytoskeleton accompany aluminum-induced growth inhibition and morphological changes in primary roots of maize," Plant Physiology, vol. 118, no. 1, pp. 159-172, 1998.

[29] W. J. Horst, N. Schmohl, M. Kollmeier, F. Baluška, and M. Sivaguru, "Does aluminium affect root growth of maize through interaction with the cell wall-plasma membranecytoskeleton continuum?" Plant and Soil, vol. 215, no. 2, pp. 163-174, 1999.

[30] G. Frantzios, B. Galatis, and P. Apostolakos, "Aluminium causes variable responses in actin filament cytoskeleton of the root tip cells of Triticum turgidum," Protoplasma, vol. 225, no. 3-4, pp. 129-140, 2005.

[31] J. Zhang, Z. He, H. Tian, G. Zhu, and X. Peng, "Identification of aluminium-responsive genes in rice cultivars with different aluminium sensitivities," Journal of Experimental Botany, vol. 58, no. 8, pp. 2269-2278, 2007.

[32] K. Krishnan and P. D. J. Moens, "Structure and functions of profilins," Biophysical Reviews, vol. 1, pp. 71-81, 2009.

[33] S. Ramachandran, H. E. M. Christensen, Y. Ishimaru et al., "Profilin plays a role in cell elongation, cell shape maintenance, and flowering in Arabidopsis," Plant Physiology, vol. 124, no. 4, pp. 1637-1647, 2000.

[34] M. Sivaguru, F. Baluška, D. Volkmann, H. H. Felle, and W. J. Horst, "Impacts of aluminum on the cytoskeleton of the maize root apex. Short-term effects on the distal part of the transition zone," Plant Physiology, vol. 119, no. 3, pp. 10731082, 1999.

[35] R. J. Bennet and C. M. Breen, "The aluminium signal: new dimensions to mechanisms of aluminium tolerance," Plant and Soil, vol. 134, no. 1, pp. 153-166, 1991.

[36] M. Sivaguru and W. J. Horst, "The distal part of the transition zone is the most aluminum-sensitive apical root zone of maize," Plant Physiology, vol. 116, no. 1, pp. 155-163, 1998.

[37] Y. Yamamoto, Y. Kobayashi, and H. Matsumoto, "Lipid peroxidation is an early symptom triggered by aluminum, but not the primary cause of elongation inhibition in Pea roots," Plant Physiology, vol. 125, no. 1, pp. 199-208, 2001.

[38] Y. Yamamoto, Y. Kobayashi, S. R. Devi, S. Rikiishi, and H. Matsumoto, "Oxidative stress triggered by aluminum in plant roots," Plant and Soil, vol. 255, no. 1, pp. 239-243, 2003.

[39] P. R. S. Boscolo, M. Menossi, and R. A. Jorge, "Aluminuminduced oxidative stress in maize," Phytochemistry, vol. 62, no. 2, pp. 181-189, 2003.

[40] M. C. Kuo and C. H. Kao, "Aluminum effects on lipid peroxidation and antioxidative enzyme activities in rice leaves," Biologia Plantarum, vol. 46, no. 1, pp. 149-152, 2003.

[41] D. L. Jones, E. B. Blancaflor, L. V. Kochian, and S. Gilroy, "Spatial coordination of aluminium uptake, production of reactive oxygen species, callose production and wall rigidification in maize roots," Plant, Cell and Environment, vol. 29, no. 7, pp. 1309-1318, 2006.

[42] Q. Liu, J. L. Yang, L. S. He, Y. Y. Li, and S. J. Zheng, "Effect of aluminum on cell wall, plasma membrane, antioxidants and root elongation in triticale," Biologia Plantarum, vol. 52, no. 1, pp. 87-92, 2008.

[43] Q. Liu, L. Zhu, L. Yin, C. Hu, and L. Chen, "Cell wall pectin and its binding capacity contribute to aluminium resistance in buckwheat," in Proceedings of the 2nd International Conference on Bioinformatics and Biomedical Engineering (ICBBE '08), pp. 4508-4511, Shanghai, China, May 2006.

[44] D. L. Jones and L. V. Kochian, "Aluminum interaction with plasma membrane lipids and enzyme metal binding sites and its potential role in Al cytotoxicity," FEBS Letters, vol. 400, no. 1, pp. 51-57, 1997.

[45] T. Guo, G. Zhang, M. Zhou, F. Wu, and J. Chen, "Effects of aluminum and cadmium toxicity on growth and antioxidant enzyme activities of two barley genotypes with different $\mathrm{Al}$ resistance," Plant and Soil, vol. 258, no. 1-2, pp. 241-248, 2004.

[46] P. H. P. Peixoto, J. Cambraia, R. Sant’Anna, P. R. Mosquim, and M. A. Moreira, "Aluminum effects on lipid peroxiadation and on the activities of enzymes of oxidative metabolism in sorghum," Revista Brasileira de Fisiologia Vegetal, vol. 11, pp. 137-143, 1999.

[47] S. K. Panda, L. B. Singha, and M. H. Khan, "Does aluminium phytotoxicity induce oxidative stress in greengram (Vigna radiata)?" Bulgarian Journal of Plant Physiology, vol. 29, pp. 77-86, 2003.

[48] M. A. Hossain, A. K. M. Z. Hossain, T. Kihara, H. Koyama, and T. Hara, "Aluminum-induced lipid peroxidation and lignin deposition are associated with an increase in $\mathrm{H}_{2} \mathrm{O}_{2}$ generation in wheat seedlings," Soil Science and Plant Nutrition, vol. 51, no. 2, pp. 223-230, 2005.

[49] S. R. Devi, Y. Yamamoto, and H. Matsumoto, "An intracellular mechanism of aluminum tolerance associated with high antioxidant status in cultured tobacco cells," Journal of Inorganic Biochemistry, vol. 97, no. 1, pp. 59-68, 2003.

[50] F. Ghanati, A. Morita, and H. Yokota, "Effects of aluminum on the growth of tea plant and activation of antioxidant system," Plant and Soil, vol. 276, no. 1-2, pp. 133-141, 2005.

[51] B. Ezaki, R. C. Gardner, Y. Ezaki, and H. Matsumoto, "Expression of aluminum-induced genes in transgenic Arabidopsis plants can ameliorate aluminum stress and/or oxidative stress," Plant Physiology, vol. 122, no. 3, pp. 657$665,2000$.

[52] G. M. A. Cançado, V. E. De Rosa, J. H. Fernandez, L. G. Maron, R. A. Jorge, and M. Menossi, "Glutathione S-transferase and aluminum toxicity in maize," Functional Plant Biology, vol. 32, no. 11, pp. 1045-1055, 2005.

[53] D. Chandran, N. Sharopova, S. Ivashuta, J. S. Gantt, K. A. VandenBosch, and D. A. Samac, "Transcriptome profiling identified novel genes associated with aluminum toxicity, resistance and tolerance in Medicago truncatula," Planta, vol. 228, no. 1, pp. 151-166, 2008.

[54] L. G. Maron, M. Kirst, C. Mao, M. J. Milner, M. Menossi, and L. V. Kochian, "Transcriptional profiling of aluminum toxicity and tolerance responses in maize roots," New Phytologist, vol. 179, no. 1, pp. 116-128, 2008.

[55] Z. Rengel and R. J. Reid, "Uptake of Al across the plasma membrane of plant cells," Plant and Soil, vol. 192, no. 1, pp. 31-35, 1997. 
[56] S. Marienfeld, H. Lehmann, and R. Stelzer, "Ultrastructural investigations and EDX-analyses of Al-treated oat (Avena sativa) roots," Plant and Soil, vol. 171, no. 1, pp. 167-173, 1995.

[57] N. Schmohl and W. J. Horst, "Cell wall pectin content modulates aluminium sensitivity of Zea mays (L.) cells grown in suspension culture," Plant, Cell and Environment, vol. 23, no. 7, pp. 735-742, 2000.

[58] Y. C. Chang, Y. Yamamoto, and H. Matsumoto, "Accumulation of aluminium in the cell wall pectin in cultured tobacco (Nicotiana tabacum L.) cells treated with a combination of aluminium and iron," Plant, Cell and Environment, vol. 22, no. 8, pp. 1009-1017, 1999.

[59] Le Van Hoa, S. Kuraishi, and N. Sakurai, "Aluminuminduced rapid root inhibition and changes in cell-wall components of squash seedlings," Plant Physiology, vol. 106, no. 3, pp. 971-976, 1994.

[60] A. K. M. Zakir Hossain, H. Koyama, and T. Hara, "Growth and cell wall properties of two wheat cultivars differing in their sensitivity to aluminum stress," Journal of Plant Physiology, vol. 163, no. 1, pp. 39-47, 2006.

[61] A. Tabuchi and H. Matsumoto, "Changes in cell-wall properties of wheat (Triticum aestivum) roots during aluminuminduced growth inhibition," Physiologia Plantarum, vol. 112, no. 3, pp. 353-358, 2001.

[62] J. Xia, N. Yamaji, T. Kasai, and J. F. Ma, "Plasma membranelocalized transporter for aluminum in rice," Proceedings of the National Academy of Sciences of the United States of America, vol. 107, no. 43, pp. 18381-18385, 2010.

[63] M. A. Akeson, D. N. Munns, and R. G. Burau, "Adsorption of $\mathrm{Al}^{3+}$ to phosphatidylcholine vesicles," Biochimica et Biophysica Acta, vol. 986, no. 1, pp. 33-40, 1989.

[64] T. B. Kinraide, P. R. Ryan, and L. V. Kochian, "Interactive effects of $\mathrm{Al}^{3+}, \mathrm{H}^{+}$, and other cations on root elongation considered in terms of cell-surface electrical potential," Plant Physiology, vol. 99, no. 4, pp. 1461-1468, 1992.

[65] S. J. Ahn, M. Sivaguru, G. C. Chung, Z. Rengel, and H. Matsumoto, "Aluminium-induced growth inhibition is associated with impaired efflux and influx of $\mathrm{H}^{+}$across the plasma membrane in root apices of squash (Cucurbita pepo)," Journal of Experimental Botany, vol. 53, no. 376, pp. 19591966, 2002.

[66] B. E. Nichol, L. A. Oliveira, A. D. M. Glass, and M. Y. Siddiqi, "The effects of aluminum on the influx of calcium, potassium, ammonium, nitrate, and phosphate in an aluminumsensitive cultivar of barley (Hordeum vulgare L.)," Plant Physiology, vol. 101, no. 4, pp. 1263-1266, 1993.

[67] C. Poschenrieder, M. Llugany, and J. Barcelo, "Short-term effects of $\mathrm{pH}$ and aluminium on mineral nutrition in maize varieties differing in proton and aluminium tolerance," Journal of Plant Nutrition, vol. 18, no. 7, pp. 1495-1507, 1995.

[68] E. D. Mariano and W. G. Keltjens, "Long-term effects of aluminum exposure on nutrient uptake by maize genotypes differing in aluminum resistance," Journal of Plant Nutrition, vol. 28, no. 2, pp. 323-333, 2005.

[69] M. A. Piñeros and L. V. Kochian, "A patch-clamp study on the physiology of aluminum toxicity and aluminum tolerance in maize. Identification and characterization of $\mathrm{Al}^{3+}$ anion channels," Plant Physiology, vol. 125, no. 1, pp. 292-305, 2001.

[70] E. Olivares, E. Peña, E. Marcano et al., "Aluminum accumulation and its relationship with mineral plant nutrients in 12 pteridophytes from Venezuela," Environmental and Experimental Botany, vol. 65, no. 1, pp. 132-141, 2009.
[71] A. Giannakoula, M. Moustakas, P. Mylona, I. Papadakis, and T. Yupsanis, "Aluminum tolerance in maize is correlated with increased levels of mineral nutrients, carbohydrates and proline, and decreased levels of lipid peroxidation and $\mathrm{Al}$ accumulation," Journal of Plant Physiology, vol. 165, no. 4, pp. 385-396, 2008.

[72] S. Silva, O. Pinto-Carnide, P. Martins-Lopes, M. Matos, H. Guedes-Pinto, and C. Santos, "Differential aluminium changes on nutrient accumulation and root differentiation in an Al sensitive vs. tolerant wheat," Environmental and Experimental Botany, vol. 68, no. 1, pp. 91-98, 2010.

[73] S. Silva, C. Santos, M. Matos, and O. Pinto-Carnide, "Al toxicity mechanisms in tlerant and sensitive rye genotypes," Environmental and Experimental Botany, vol. 75, pp. 89-97, 2011.

[74] F. C. Lidon, H. G. Azinheira, and M. G. Barreiro, "Aluminum toxicity in maize: biomass production and nutrient uptake and translocation," Journal of Plant Nutrition, vol. 23, no. 2, pp. 151-160, 2000.

[75] R. J. de Mendonça, J. Cambraia, J. A. de Oliveira, and M. A. Oliva, "Aluminum effects on the uptake and utilization of macronutrients in two rice cultivars," Pesquisa Agropecuaria Brasileira, vol. 38, no. 7, pp. 843-848, 2003.

[76] L. Simon, T. J. Smalley, J. Benton Jones Jnr, and F. T. Lasseigne, "Aluminum toxicity in tomato .1. Growth and mineral-nutrition," Journal of Plant Nutrition, vol. 17, no. 23, pp. 293-306, 1994.

[77] Z. Rengel and W. H. Zhang, "Role of dynamics of intracellular calcium in aluminium-toxicity syndrome," New Phytologist, vol. 159, no. 2, pp. 295-314, 2003.

[78] S. Silva, Aluminium Toxicology in Wheat and Rye [Ph.D. thesis], Biologia Universidade de Aveiro, Aveiro, Portugal, 2011.

[79] C. H. Huang and R. C. Crain, "Phosphoinositide-specific phospholipase $\mathrm{C}$ in oat roots: association with the actin cytoskeleton," Planta, vol. 230, no. 5, pp. 925-933, 2009.

[80] W. H. Zhang and Z. Rengel, "Aluminium induces an increase in cytoplasmic calcium in intact wheat root apical cells," Australian Journal of Plant Physiology, vol. 26, no. 5, pp. 401409, 1999.

[81] P. Bhuja, K. McLachlan, J. Stephens, and G. Taylor, "Accumulation of $1,3-\beta$-D-glucans, in response to aluminum and cytosolic calcium in Triticum aestivum," Plant and Cell Physiology, vol. 45, no. 5, pp. 543-549, 2004.

[82] D. L. Jones, S. Gilroy, P. B. Larsen, S. H. Howell, and L. V. Kochian, "Effect of aluminum on cytoplasmic $\mathrm{Ca}^{2+}$ homeostasis in root hairs of Arabidopsis thaliana (L.)," Planta, vol. 206, no. 3, pp. 378-387, 1998.

[83] A. C. Jorns, C. Hechtbuchholz, and A. H. Wissemeier, "Aluminum-induced callose formation in root-tips of Norway spruce (Picea-Abies (L) Karst)," Zeitschrift Fur Pflanzenernahrung Und Bodenkunde, vol. 154, pp. 349-353, 1991.

[84] K. A. Schreiner, J. Hoddinott, and G. J. Taylor, "Aluminuminduced deposition of (1,3)-beta-glucans (Callose) in Triticum aestivum L.," Plant and Soil, vol. 162, no. 2, pp. 273-280, 1994.

[85] D. Eticha, C. Thé, C. Welcker, L. Narro, A. Staß, and W. J. Horst, "Aluminium-induced callose formation in root apices: inheritance and selection trait for adaptation of tropical maize to acid soils," Field Crops Research, vol. 93, no. 2-3, pp. 252-263, 2005.

[86] K. Tahara, M. Norisada, T. Hogetsu, and K. Kojima, "Aluminum tolerance and aluminum-induced deposition of callose and lignin in the root tips of Melaleuca and Eucalyptus 
species," Journal of Forest Research, vol. 10, no. 4, pp. 325-333, 2005.

[87] W. J. Horst, A. K. Püschel, and N. Schmohl, "Induction of callose formation is a sensitive marker for genotypic aluminium sensitivity in maize," Plant and Soil, vol. 192, no. 1, pp. 23-30, 1997.

[88] N. Massot, M. Llugany, C. Poschenrieder, and J. Barceló, "Callose production as indicator of aluminum toxicity in bean cultivars," Journal of Plant Nutrition, vol. 22, no. 1, pp. 1-10, 1999.

[89] B. Meriga, B. K. Reddy, G. Jogeswar, L. A. Reddy, and P. B. K. Kishor, "Alleviating effect of citrate on aluminium toxicity of rice (Oryza sativa L.) seedlings," Current Science, vol. 85, no. 3, pp. 383-386, 2003.

[90] Y. Hirano, E. G. Pannatier, S. Zimmermann, and I. Brunner, "Induction of callose in roots of Norway spruce seedlings after short-term exposure to aluminum," Tree Physiology, vol. 24, no. 11, pp. 1279-1283, 2004.

[91] N. E. Nagy, L. S. Dalen, D. L. Jones, B. Swensen, C. G. Fossdal, and T. D. Eldhuset, "Cytological and enzymatic responses to aluminium stress in root tips of Norway spruce seedlings," New Phytologist, vol. 163, no. 3, pp. 595-607, 2004.

[92] M. Sivaguru, T. Fujiwara, J. Samaj et al., "Aluminum-induced 133-b-D-glucan inhibits cell-to-cell trafficking of molecules through plasmodesmata. A new mechanism of aluminum toxicity in plants," Plant Physiology, vol. 124, no. 3, pp. 991$1005,2000$.

[93] J. Barceló and C. Poschenrieder, "Fast root growth responses, root exudates, and internal detoxification as clues to the mechanisms of aluminium toxicity and resistance: a review," Environmental and Experimental Botany, vol. 48, no. 1, pp. 75-92, 2002.

[94] M. Moustakas, G. Ouzounidou, E. P. Eleftheriou, and R. Lannoye, "Indirect effects of aluminium stress on the function of the photosynthetic apparatus," Plant Physiology and Biochemistry, vol. 34, no. 4, pp. 553-560, 1996.

[95] A. Konarska, "Effects of aluminum on growth and structure of red pepper (Capsicum annuum L.) leaves," Acta Physiologiae Plantarum, vol. 32, no. 1, pp. 145-151, 2010.

[96] R. Azmat and S. Hasan, "Photochemistry of light harvesting pigments and some biochemical changes under aluminium stress," Pakistan Journal of Botany, vol. 40, no. 2, pp. 779-784, 2008.

[97] X. B. Zhang, P. Liu, Y. S. Yang, and G. D. Xu, "Effect of Al in soil on photosynthesis and related morphological and physiological characteristics of two soybean genotypes," Botanical Studies, vol. 48, no. 4, pp. 435-444, 2007.

[98] T. R. Guo, G. P. Zhang, and Y. H. Zhang, "Physiological changes in barley plants under combined toxicity of aluminum, copper and cadmium," Colloids and Surfaces B, vol. 57, no. 2, pp. 182-188, 2007.

[99] H. X. Jiang, L. S. Chen, J. G. Zheng, S. Han, N. Tang, and B. R. Smith, "Aluminum-induced effects on Photosystem II photochemistry in Citrus leaves assessed by the chlorophyll a fluorescence transient," Tree Physiology, vol. 28, no. 12, pp. 1863-1871, 2008.

[100] L. S. Chen, Y. P. Qi, B. R. Smith, and X. H. Liu, "Aluminuminduced decrease in $\mathrm{CO}_{2}$ assimilation in citrus seedlings is unaccompanied by decreased activities of key enzymes involved in $\mathrm{CO}_{2}$ assimilation," Tree Physiology, vol. 25, no. 3, pp. 317-324, 2005.

[101] F. C. Lidon, M. G. Barreiro, J. C. Ramalho, and J. A. Lauriano, "Effects of aluminum toxicity on nutrient accumulation in maize shoots: implications on photosynthesis," Journal of Plant Nutrition, vol. 22, no. 2, pp. 397-416, 1999.

[102] M. Reyes-Díaz, C. Inostroza-Blancheteau, R. Millaleo et al., "Long-term aluminum exposure effects on physiological and biochemical features of highbush blueberry cultivars," Journal of the American Society for Horticultural Science, vol. 135, no. 3, pp. 212-222, 2010.

[103] Y. Cao, Y. Lou, Y. Han et al., "Al toxicity leads to enhanced cell division and changed photosynthesis in Oryza rufipogon L.," Molecular Biology Reports, vol. 38, no. 8, pp. 4839-4846, 2011. 

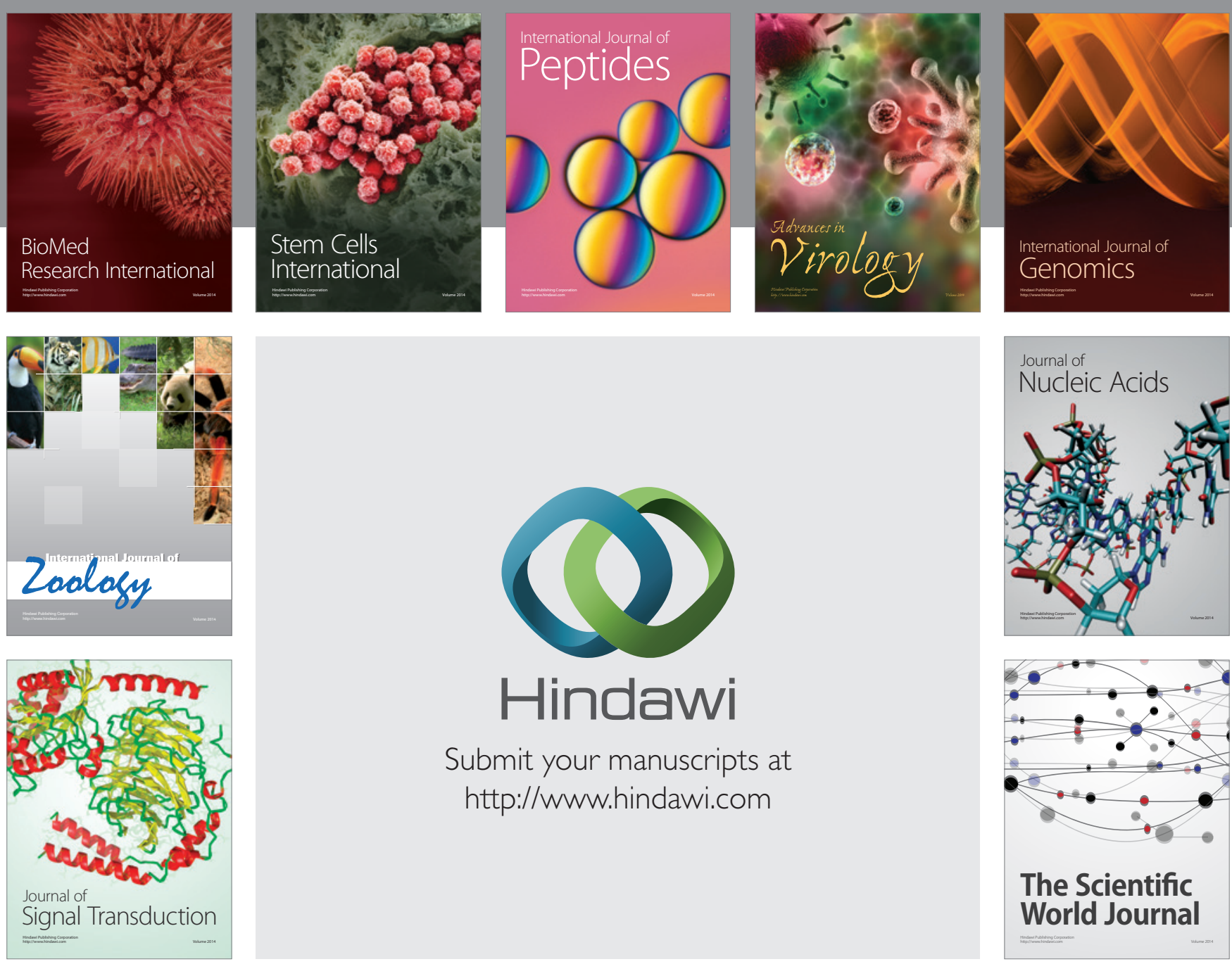

Submit your manuscripts at

http://www.hindawi.com
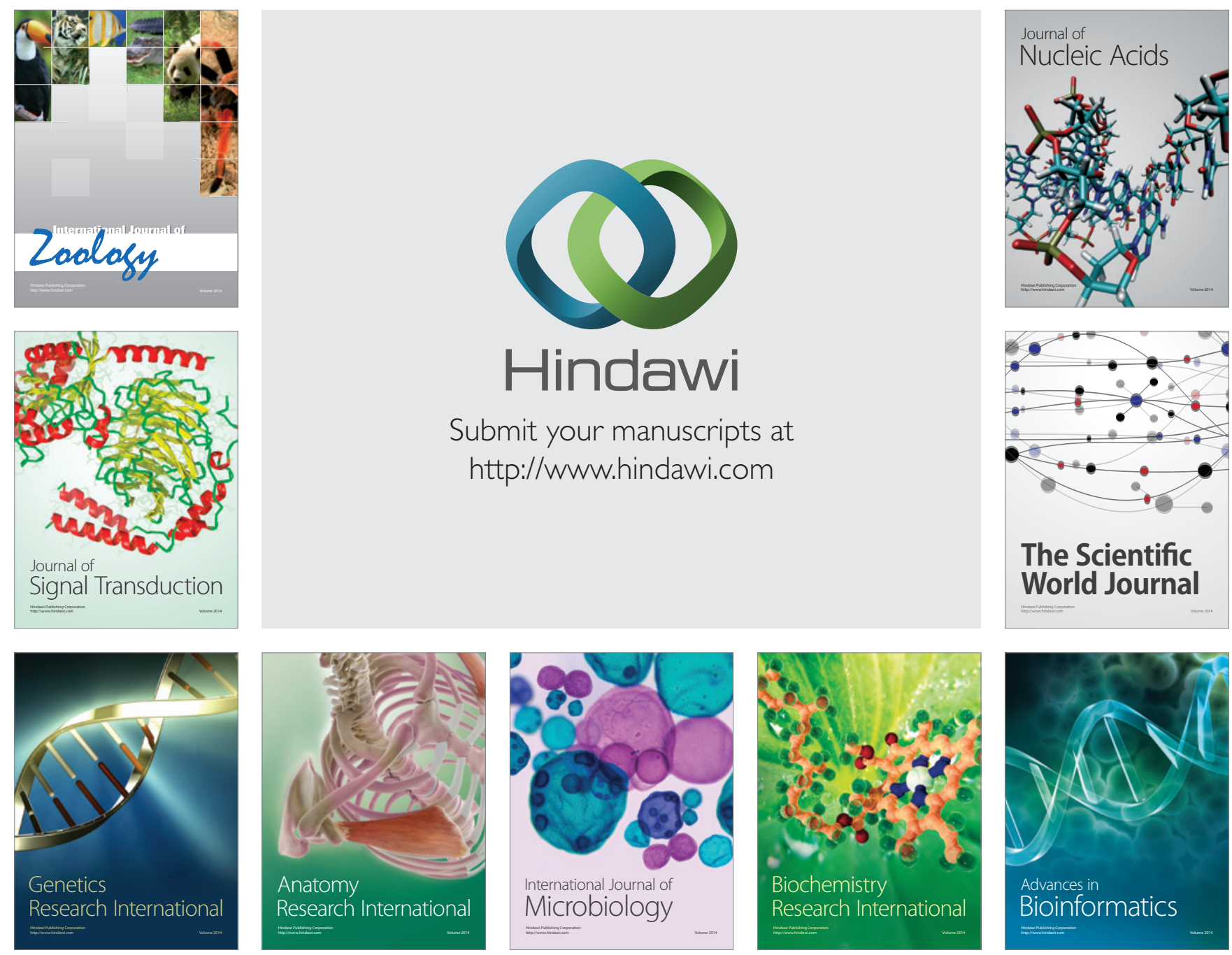

The Scientific World Journal
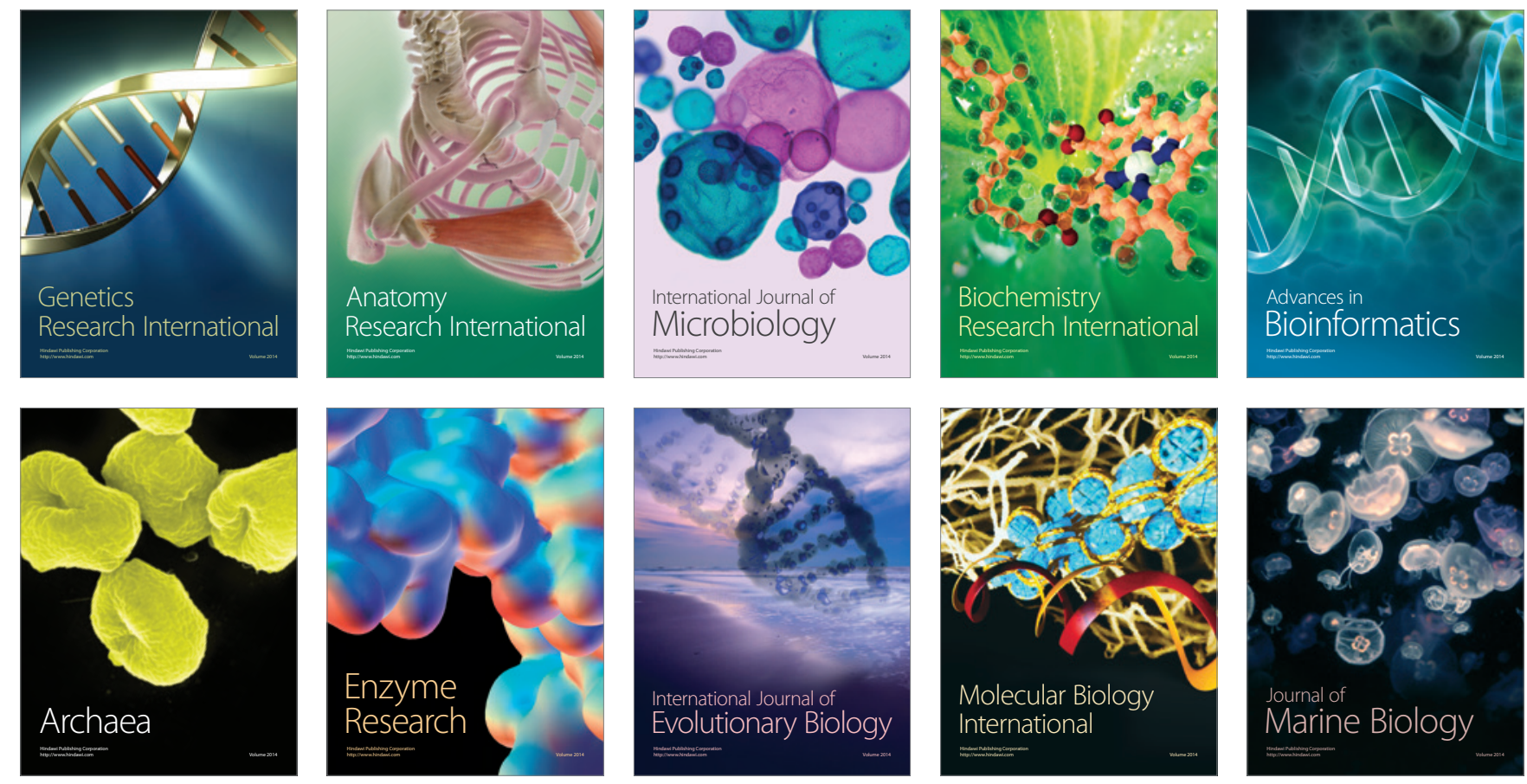